\title{
Detection and molecular characterization of phytoplasma affecting vegetables in Eastern Visayas, Philippines
}

\author{
Lucia M. Borines ${ }^{1 *}$, Joy Adeline C. Nuñez', Nickie D. Duero', Rezel S. Borines ${ }^{2}$ \\ and Reny G. Gerona'
}

\begin{abstract}
Submitted: 13 June 2019 | Accepted: 9 June 2020

Phytoplasma-like diseases were observed affecting bitter gourd, Loofah, string bean, "Baguio" bean, cucumber, and tomato in Eastern Visayas, Philippines. The infected vegetables commonly show little leaf/witches' broom symptoms. The study aimed to detect and confirm phytoplasma's presence in these vegetables through PCR and nest PCR assays using universal primers, electron microscopy, and 16 srDNA sequence analysis. Loofah little leaf had the highest prevalence (50\% of the surveyed farms), followed by bitter gourd (45\%) and string beans (31\%). The disease had an approximate mean incidence of $27 \%$ for bitter gourd, $38.0 \%$ for Loofah, and $42.5 \%$ for string bean, in farms where plants showed infections. Electron micrographs of bitter gourd and Loofah samples showed phytoplasma cells in the phloem sieve tubes. Nest PCR assays using R16F2n/R16R2 primer linked to phytoplasma 16 srDNA amplified a $\sim 1.25 \mathrm{~Kb}$ band in the majority of DNA samples. rDNA sequence analysis using Blastn showed that phytoplasmas in bitter gourd, Loofah, and one cucumber samples shared $98-99 \%$ identity with Loofah's reference gene phytoplasma clones. More than one phytoplasma strain infected the vegetables based on Rsa1 enzyme digestion and phylogenetic analysis.
\end{abstract}

Keywords: witches broom, PCR, bitter gourd rDNA sequence

\section{INTRODUCTION}

Phytoplasma is an ultramicroscopic, wall-less specialized bacterium belonging to the Mollicutes that resides in the plants' phloem. Little leaf, witches' broom phyllody, and virescence are some of the visible symptoms caused by this pathogen in plants (Bertaccini 2007). Phytoplasma diseases pose a severe threat to

'Department of Pest Management, Visayas State University, Baybay City-6521, Leyte, Philippines

${ }^{2}$ Caraga State University, Ampayon, Butuan City, Agusan del Norte

*Corresponding Author. Address: Department of Pest Management, Visayas State University, Baybay City6521, Leyte, Philippines; Email: lucyborines@vsu.edu.ph

DOI: 10.32945/atr4221.2020 
agriculture (Bertaccini et al 2014). The reduction in the size of leaves and fruits of affected plants eventually leads to reduced yield due to stunted growth and production of smaller fruits.

Unlike fungal and bacterial diseases, phytoplasma could not be detected using common clinical examination protocols in the laboratory. Phytoplasma diseases were once thought to be caused by viruses (Bertaccini \& Duduk 2009) because the type of symptoms exhibited by infected plants resemble those of virus diseases. Molecular detection of the pathogen is cheaper than electron microscopy and is commonly performed through PCR and nested PCR using universal phytoplasma primers (Kummert \& Rufflard 1997, Gundersen \& Lee 1996). Differentiation of strains at the molecular level can also be achieved using RFLP and rDNA sequence analysis (Bertaccini 2007, Schneider et al 1997, Montano et al 2007, Montano et al 2000, Khan et al 2003, Lee et al 1998).

In Mexico, Lebsky et al (2007) detected phytoplasma from the yellows-type disease in tomato through PCR analysis. In Brazil, Montano et al (2000; 2001; 2006; 2007) detected phytoplasma from the cucurbit Luffa cylindrical, Cucurbita moschata, diseased chayote, and hibiscus, respectively showing witches' broom symptom. Singh and Singh (2000) detected phytoplasma from chili little leaf in India. Almomani and Almuaikel (2014) detected phytoplasma from tomato, pepper, and squash in Jordan. AL-Saleh \& Amer (2014) characterized the phytoplasma associated with fava bean in Saudi Arabia. Samuel et al (2014) detected phytoplasma from pea, watermelon, tomato, amaranthus, and bottle gourd. It was also detected in witches' broom of bitter gourd in Vietnam by Nang et al (2014). Habili et al (2014) detected phytoplasma from a bitter gourd using generic primers, as well as in Loofah, bamboo, and coconut specimens from the Philippines.

Phytoplasma disease symptoms were first seen as early as 2012 in bitter gourd showing little leaf and little fruits in few vegetable farms in Leyte Philippines but formal study on it started in 2015. These little leaf symptoms were observed later in Loofah, stringbean, "Baguio" bean cucumber, and tomato. Knowledge of phytoplasma diseases is insufficient, particularly the ones affecting vegetables, hence the need to detect the presence of this emerging disease. The causal organism needs to be characterized so that specific programs for its prevention and control can be formulated. This study was conducted to detect and characterize phytoplasma diseases affecting vegetables in Leyte using PCR and nest-PCR assays and rDNA gene sequencing.

\section{MATERIALS AND METHODS}

\section{Survey and Collection of Disease Specimens}

Vegetable areas in Eastern Visayas were surveyed for phytoplasma disease symptoms. A total of 16 municipalities and 5 cities in Eastern Visayas were surveyed, but the disease was observed mostly in Leyte. Bitter gourd and Loofah were not commonly planted in Samar during the survey. The disease prevalence (Percentage of farms where the disease has been recorded over the total number of surveyed farms) and the mean disease incidence (\% infection) per farm was determined. Diseased specimens were brought to the Plant Disease Diagnostic Laboratory of Visayas State University for DNA extraction and phytoplasma detection. 


\section{Detection and molecular characterization of phytoplasma}

\section{Total Genomic DNA Extraction}

Leaf and stem tissues of vegetables that showed little leaf/witches' broom symptoms were subjected to total DNA extraction. An optimized extraction protocol for phytoplasma used by Ahrens and Seemüller (1992) was slightly modified. In this method, $0.5 \mathrm{~g}$ of shoots from each vegetable sample was soaked in a mortar containing $2 \mathrm{~mL}$ phytoplasma grinding buffer $\left(100 \mathrm{mM} \mathrm{K}_{2} \mathrm{HPO}_{4}, 31 \mathrm{mM} \mathrm{KH}_{2} \mathrm{PO}_{4}, 10 \%\right.$ sucrose, $2 \%$ polyvinylpyrrolidone- 10 (PVP-10), $10 \mathrm{mM}$ EDTA pH8.0) and kept at $-4^{\circ} \mathrm{C}$ for $10 \mathrm{~min}$. The tissue was then ground with a pestle and the homogenate was centrifuged at $5000 \mathrm{rpm}$ for $5 \mathrm{~min}$. The supernatant was transferred into a clean $2 \mathrm{~mL}$ tube and further centrifuged at $13000 \mathrm{rpm}$ for $30 \mathrm{~min}$. The pellet was dissolved in $750 \mu \mathrm{L}$ warm $2 \%$ CTAB (20 g L ${ }^{-1}$ CTAB, $100 \mathrm{mM}$ Tris- $\mathrm{HCl}$ pH8.0, 1.4M NaCl, 2\% PVP-10, $20 \mathrm{mM}$ EDTA pH8.0) and incubated at $60^{\circ} \mathrm{C}$ for $30 \mathrm{~min}$. Each sample was purified with $900 \mu \mathrm{L}$ chloroform-isoamyl alcohol (24:1) and centrifuged at 12000rpm for $5 \mathrm{~min}$. Nucleic acids were precipitated with $600 \mu \mathrm{L}$ isopropanol before incubating at $-20^{\circ} \mathrm{C}$ overnight. Samples were centrifuged at $12000 \mathrm{rpm}$ for $30 \mathrm{~min}$ and washed with $70 \%$ ethanol. The pellets were air-dried and re-suspended in $100 \mu \mathrm{L} \mathrm{TE}(10 \mathrm{mM}$ Tris-HCl, $1 \mathrm{mM}$ EDTA, pH8.0) buffer. Two further extractions, first with $100 \mu \mathrm{L}$ phenol: chloroform: isoamyl alcohol (25:24:1), and then $100 \mu \mathrm{L}$ chloroform followed. The upper aqueous layer was removed, and $300 \mu \mathrm{L}$ of absolute cold ethanol was added to precipitate the nucleic acids. DNAs were centrifuged at $13000 \mathrm{rpm}$ for $30 \mathrm{~min}$, washed with cold $300 \mu \mathrm{L} 70 \%$ ethanol, air-dried, and re-suspended in $10-40 \mu \mathrm{L} \mathrm{TE}$ buffer. Two $\mu \mathrm{L}$ RNAse were added to each tube and incubated at $37^{\circ} \mathrm{C}$ for $30 \mathrm{~min}$. Nucleic acids were then stored at $-20^{\circ} \mathrm{C}$.

\section{PCR and Nest PCR Assays}

Initial PCR analysis was done using the universal primer $\mathrm{P}_{1} / \mathrm{P}_{7}$ for phytoplasma developed by Deng and Hiruki (1991), followed by a nested PCR using the primer $R_{16} F_{2} n / R_{16} R_{2}$ (Gundersen \& Lee 1996, Lee et al 1995). Nest PCR reactions were carried out in a total volume of $25 \mu \mathrm{L}$. Each reaction was composed of nuclease-free water, $2.5 \mu \mathrm{L}$ GoTaq buffer (GoTaq Green, Promega, Madison, USA), 0.5 $\mu \mathrm{L} 10 \mathrm{mM}$ dNTPs (Vivantis), $1 \mu \mathrm{L}$ of $50 \mathrm{nM}$ each of forward primer $\left(\mathrm{R}_{16} \mathrm{~F}_{2} \mathrm{n}\right)$ and reverse primer $\left(\mathrm{R}_{16} \mathrm{R}_{2}\right)$, $0.5 \mu \mathrm{L}$ Taq Polymerase enzyme, and $2 \mu \mathrm{L}$ of $50 \mathrm{ng} \mu_{\mathrm{L}^{-1}}$ template DNA. PCR conditions were as follows: initial denaturation at $94^{\circ}$ for $2 \mathrm{~min} ; 30$ cycles of denaturation at $92^{\circ}$ for $1 \mathrm{~min}$; annealing at $55^{\circ}$ for $15 \mathrm{~s}$ and extension $72^{\circ}$ for $30 \mathrm{~s}$; and a final extension at $72^{\circ}$ for $10 \mathrm{~min}$. The PCR products were subjected to agarose gel electrophoresis using $1 \%$ agarose, stained with GelRed (Biotium). The bands were viewed under UV transilluminator attached to an Alpha Digi-Doc Documentation System.

\section{Electron Microscopy of Disease Specimens}

Stem and leaf samples of the bitter gourd and Loofah showing witches' broom symptoms were submitted for transmission electron microscopy at the Research Institute for Tropical Medicine (RITM) Muntinlupa City, Philippines to confirm the presence of phytoplasma in the phloem cells of the tissues. 


\section{SrDNA Sequence Analysis}

Nest PCR products amplified by $R_{16} F_{2} n / R_{16} R_{2}$ primers of selected samples showing positive phytoplasma bands were sent for rRNA sequence analysis at the Philippine Genome Program, University of the Philippines, Diliman, Quezon City. Sequence alignment was performed using Blastn, and phylogenetic analysis of the different isolates was conducted using the Mega6 software (Tamura 2013). The evolutionary distances were computed using the Kimura 2-parameter method (Kimura 1980), and evolutionary relationships were inferred using the UPGMA method (Sneath \& Sokal 1973).

\section{RESULTS AND DISCUSSION}

\section{Symptoms of Phytoplasma Diseases in Affected Vegetables Prevalence and Incidence}

Enumerated in Table 1 are the municipalities and cities in Eastern Visayas where phytoplasma disease symptoms were observed, together with the disease prevalence and incidence. Loofah phytoplasma had the highest prevalence ( $50 \%$ of the surveyed farms), followed by bitter gourd (45\%) and string beans (31\%). Stringbeans phytoplasma had the highest mean incidence per farm (42.5\%), followed by Loofah (38\%) and ampalaya. Cucumber phyllody and Baguio bean little leaf was found in one farm each, with $30 \%$ and $10 \%$ incidence, respectively. Tomato stunt was observed and taken from a single plant in a farm. PCR analysis were conducted in disease samples from the municipalities like Baybay, Inopacan, Hindang, Hilongos in Leyte and as far as Maasin City in Southern Leyte where phytoplasma disease was more common. The affected vegetables commonly exhibited little leaf and witches' broom symptoms and little fruit when able to bear.

The infected bitter gourd produced tiny leaves, with or without yellowing, small elongated fruits (shoestring symptom), and sometimes stem pitting (Figures 1a1b). Little leaf was also the symptom of phytoplasma infection in Loofah (Figure 1c), string bean (Figure 1d), and "Baguio" bean (1e). In cucumber, some leaves turn tiny, but phyllody symptoms can be observed (Figure 1f). Tomato infected with phytoplasma becomes stunted with little leaves (Figure 1g).

\section{Electron Microscopy of Infected Bitter gourd and Loofah}

Electron microscopy results from the Research Institute of Tropical Medicine showed few phytoplasmas (red arrows) in the phloem sieve tubes of infected bitter gourd (Figure 2a) and Loofah samples confirming the presence of the pathogen (Figure 2b). 


\section{Detection and molecular characterization of phytoplasma}

Table 1. Municipalities and cities in Eastern Visayas where phytoplasma diseases were found, the disease prevalence and mean disease incidence

\begin{tabular}{|c|c|c|c|}
\hline $\begin{array}{l}\text { Province/Municipality Surveyed } \\
\text { For Vegetable Phytoplasma Disease }\end{array}$ & $\begin{array}{l}\text { Municipalities Where Vegetable } \\
\text { Phytoplasma Was Recorded }\end{array}$ & $\begin{array}{l}\text { Disease } \\
\text { Prevalence } \\
(\%)(\%)\end{array}$ & $\begin{array}{l}\text { Mean Disease } \\
\text { Incidence (\%) }\end{array}$ \\
\hline Leyte: Province & Bittergourd Little Leaf & & \\
\hline $\begin{array}{l}\text { Abuyog, Alang-alang, Albuera, Baybay } \\
\text { City, Capoocan, Inopacan, Hindang, } \\
\text { Hilongos, Ormoc City, Palo, San } \\
\text { Isidro, and Tacloban City }\end{array}$ & $\begin{array}{l}\text { Baybay City, Inopacan, Hindang, } \\
\text { Ormoc City and Abuyog in Leyte; } \\
\text { Maasin City in Southern Leyte } \\
\text { and Lavesares, Northern Samar }\end{array}$ & 45 & 27 \\
\hline Southern Leyte: Province & Loofah Little Leaf: & & \\
\hline $\begin{array}{l}\text { Anahawan, Bontoc, Maasin City, } \\
\text { Malitbog, and Silago }\end{array}$ & $\begin{array}{l}\text { Baybay City, Inopacan, and } \\
\text { Hindang in Leyte and Maasin } \\
\text { City, Malitbog, Anahawan and } \\
\text { Silago in Southern Leyte }\end{array}$ & 50 & 38 \\
\hline Samar: Province & Stringbean Little Leaf: & & \\
\hline Calbayog City and San Jorge & $\begin{array}{l}\text { Hindang and Hilongos in Leyte } \\
\text { and Calbayog City Samar }\end{array}$ & 31 & 42.5 \\
\hline Northern Samar: Province & Cucumber Phylllody: & & \\
\hline Lavesares & Baybay City, Leyte & * & 10.0 \\
\hline Biliran: Province & Baguio Bean Little Leaf: & & 30.0 \\
\hline \multirow[t]{3}{*}{ Caibiran } & Hilongos, Leyte & * & - \\
\hline & Tomato Stunt: & & \\
\hline & Baybay City, Leyte & - & - \\
\hline
\end{tabular}

Only one plant in one farm was documented

"Only one farm was observed showing the symptom

"Refers to percentage farms where the disease was observed over the total number of surveyed farms in Leyte

\section{Molecular Detection and Characterization of the Pathogen}

Initial PCR amplification results using the universal phytoplasma-specific primer P1/P7 by Deng and Hiruki (1991) on five infected bitter gourd and four Loofah DNA samples produced only faint bands of $\sim 1.5 \mathrm{~Kb}$ for loofah samples from VSU (PV), Inopacan (PI), and Hindang in Leyte (PHg). All bitter gourd samples and the Loofah sample from Maasin showed no bands (Figure 3). Nest PCR assay of the same samples using $R_{16} F_{2} n / R_{16} R_{2}$ primers, however, produced positive amplification (Figure 4). Bitter gourd samples collected from fields in VSU (AV2) and Guadalupe (AG), and from the screen house of the VSU Department of Pest Management (AS1 and AS2) as well as Loofah samples from VSU (PV), Inopacan (PI), and Hindang (Phg) showed the $\sim 1.25 \mathrm{~Kb}$ amplicon which is the expected phytoplasma-specific band based on the report of Lee et al $(1993,1995)$. 
Borines et al

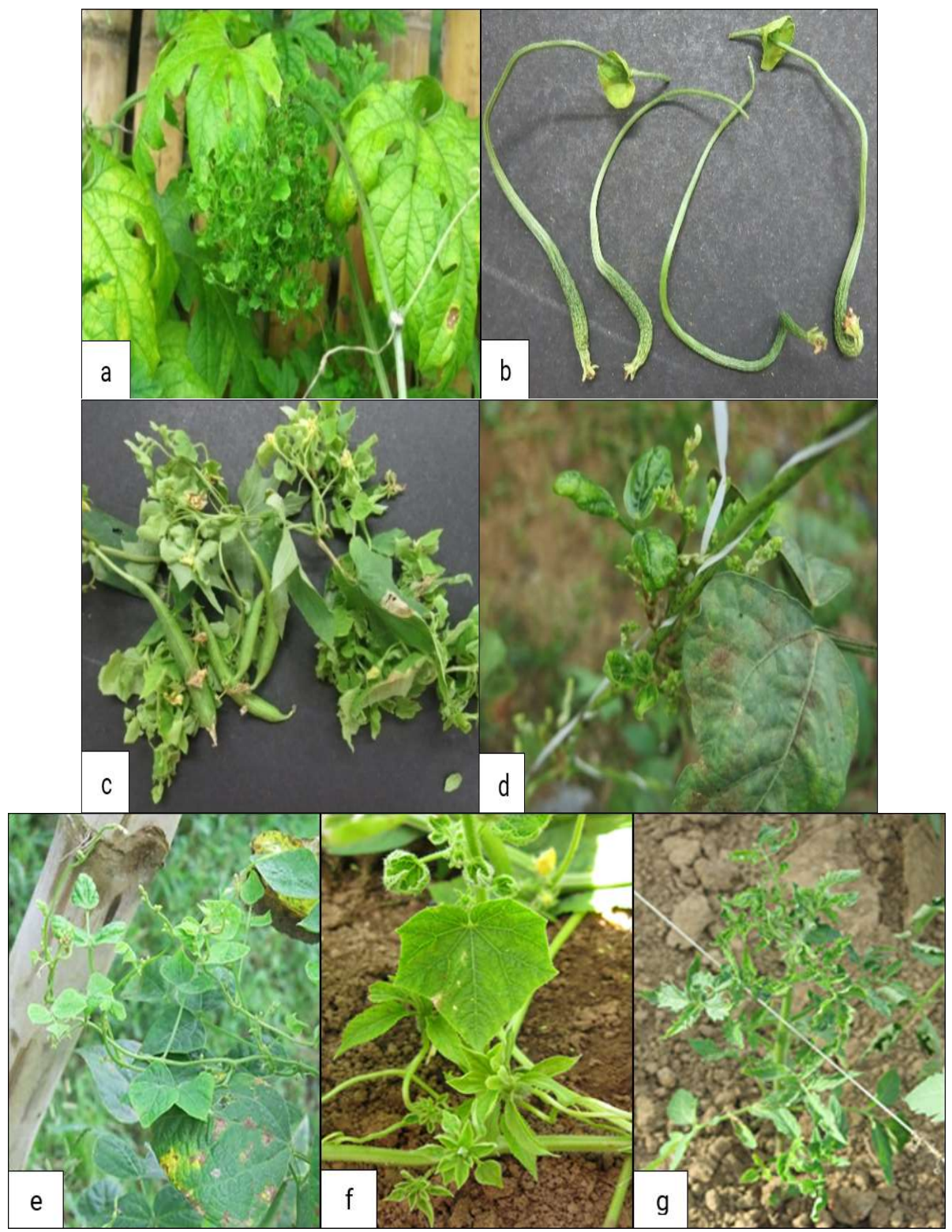

Figure 1. Phytoplasma symptoms on (a), bitter gourd leaves, b) bitter gourd fruit (c), Loofah leaf and fruit (d), string bean, "Baguio" bean (e), cucumber (f) and tomato (g) 


\section{Detection and molecular characterization of phytoplasma}

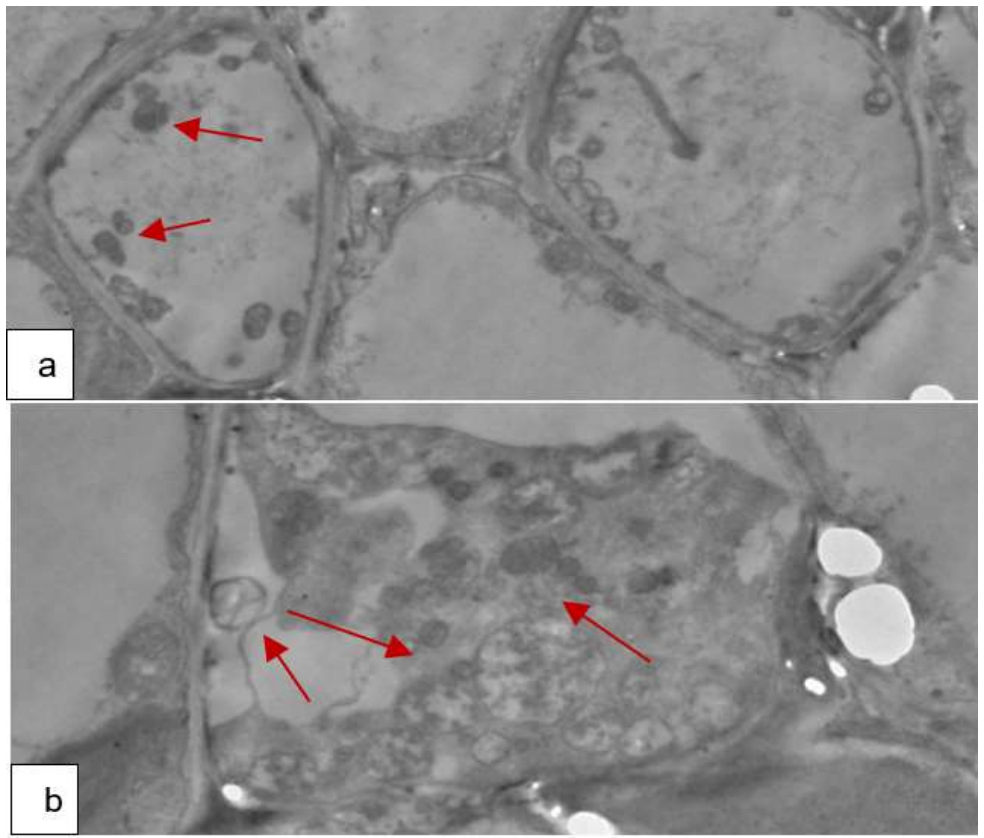

Figure 2. Electron micrographs of bitter gourd (a) and Loofah (b) affected with leaf disease showing pleomorphic phytoplasmas (arrows) in phloem cells

Interestingly, another field-collected bitter gourd DNA sample from VSU (AV1) produced a much shorter amplicon size ( 500bp), which is still within the reported band sizes of phytoplasmas affecting different crops by Duleep et al (2014). Similarly, Montano et al (2007) also reported different phytoplasma band sizes of $\sim 0.5 \mathrm{~Kb}, 0.8 \mathrm{~Kb}$, and $\sim 1.2 \mathrm{~Kb}$. This initially suggests that at least two different phytoplasma strains affecting bitter gourd exist in the Eastern Visayas region. The Loofah from Maasin City (PM) did not produce the expected band.

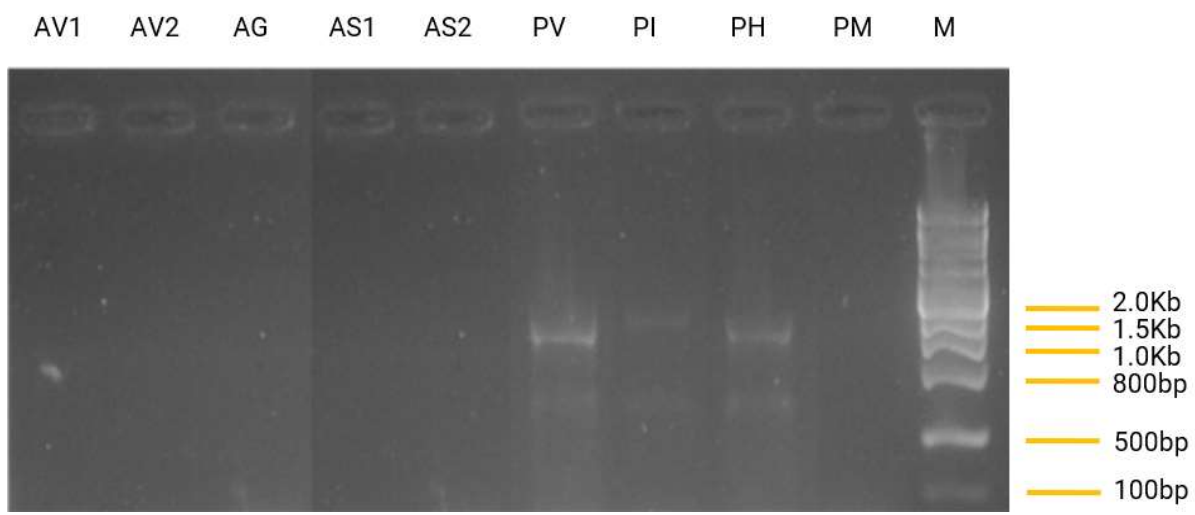

Figure 3. Initial phytoplasma amplification result using P1/P2 primer showing faint bands for a few samples. (AV1, AV2, AG, AS1, \& AS2 are bitter gourd leaf samples) and PV, PI, PHg and PM were infected Loofah leaf samples. M (DNA ladder Vivantis) 


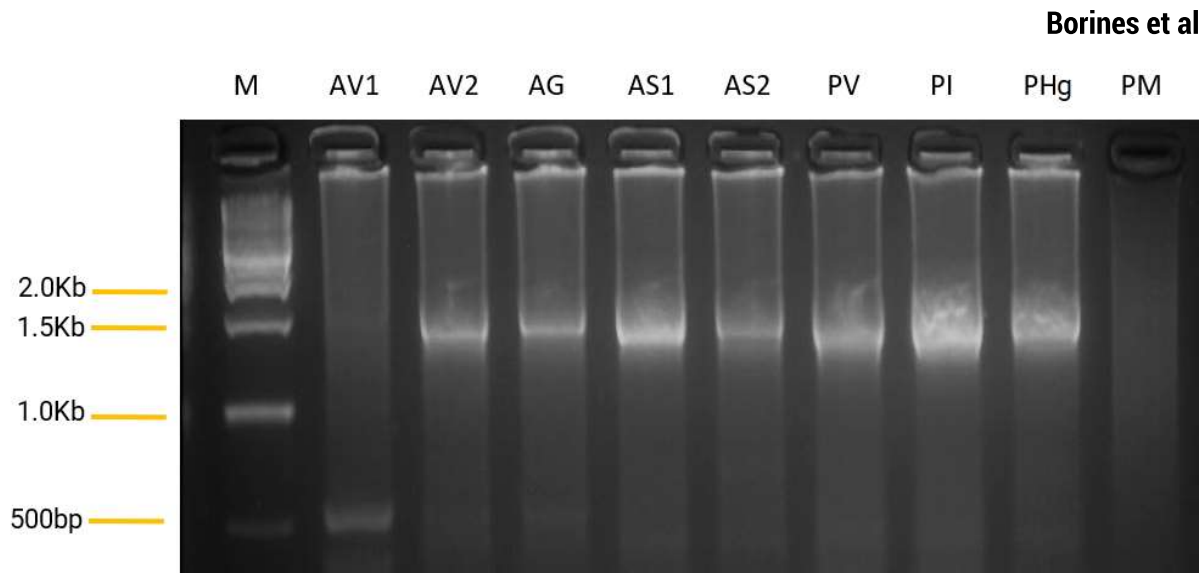

Figure 4. Nest $P C R$ amplicons using $R_{16} F_{2} n / R_{16} R_{2}$ primers of bitter gourd ( $\left.A V 1, A V 2, A G, A S 2\right)$ and Loofah (PV,PI, PHg, PM) little leaf samples. M (1 Kb DNA ladder Vivantis)

The nest PCR assay was repeated for samples AV1, AV2, and AG with another bitter gourd sample AL (Figure 5 ). The expected $\sim 1.25 \mathrm{~Kb}$ band was again amplified for samples $A V 2, A G$, and $A L$, and the $\sim 500 \mathrm{bp}$ band was produced from sample AV1, confirming that it was different from the other bitter gourd samples. Another nest PCR assay was also conducted on Loofah DNAs, PV, PI, PH, and PM, together with string bean, "Baguio" bean, tomato, and cucumber showing phytoplasma symptoms, as well as an associated insect collected from the field, ie, Ricania speculum nymphs (Figure 6). The DNA isolates from the infected Loofah samples from VSU, Inopacan, and Hindang Leyte (PV, PI \& PHg), showed that the $\sim 1.25 \mathrm{~Kb}$ band was positively amplified. However, a shorter band $(<1.0 \mathrm{~Kb})$ was amplified from the Loofah isolate from Maasin City (PM). This suggests that there is also more than one strain of phytoplasma affecting Loofah. No band was amplified from the infected string bean DNA (SB), but the $\sim 1.25 \mathrm{~Kb}$ band was amplified from "Baguio" bean (BB) and cucumber from VSU (CV). A faint, shorter DNA fragment ( 300bp) was amplified from tomato showing little leaf and stunting symptoms (TG).

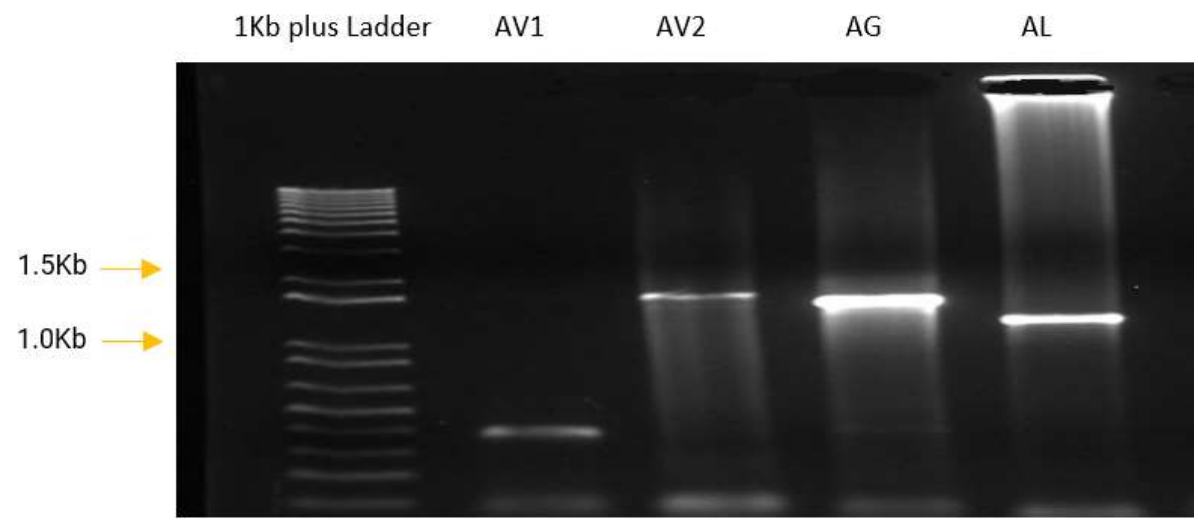

Figure 5. Nest PCR amplicons using $R_{16} F_{2} n / R_{16} R_{2}$ primers from bitter gourd little leaf from different places in Eastern Visayas (AV1, AV2, AG \& AL) amplified using phytoplasma-specific primers $R_{16} F_{2} n / R_{16} R_{2}$ 
Detection and molecular characterization of phytoplasma

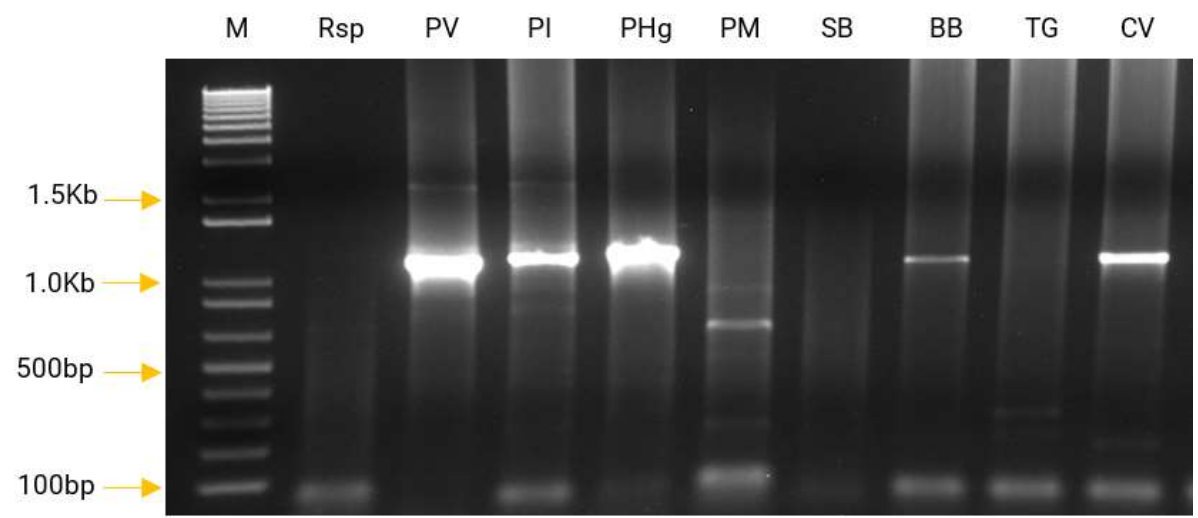

Figure 6. Nest PCR amplification results from collected suspected insect vector Ricania speculum (Rsp), field-collected infected Loofah (PV, PI, PHg \& PM), string bean (SB), "Baguio" Bean ((BB), Tomato (TG), and cucumber (CV) using R16F2n/R16R2 Phytoplasma-specific primers. $M=(100 \mathrm{bp}+$ DNAladder)

When selected DNA amplicons of some samples using $\mathrm{R}_{16} \mathrm{~F}_{2} \mathrm{n} / \mathrm{R} 16 \mathrm{R}_{2}$ primer were subjected to restriction enzyme digestion using Rsa1 enzyme, two-band patterns were observed among the bitter gourd samples and three with Loofah samples (Figure 7). This further confirmed the existence of more than one strain of phytoplasma affecting bitter gourd and Loofah.

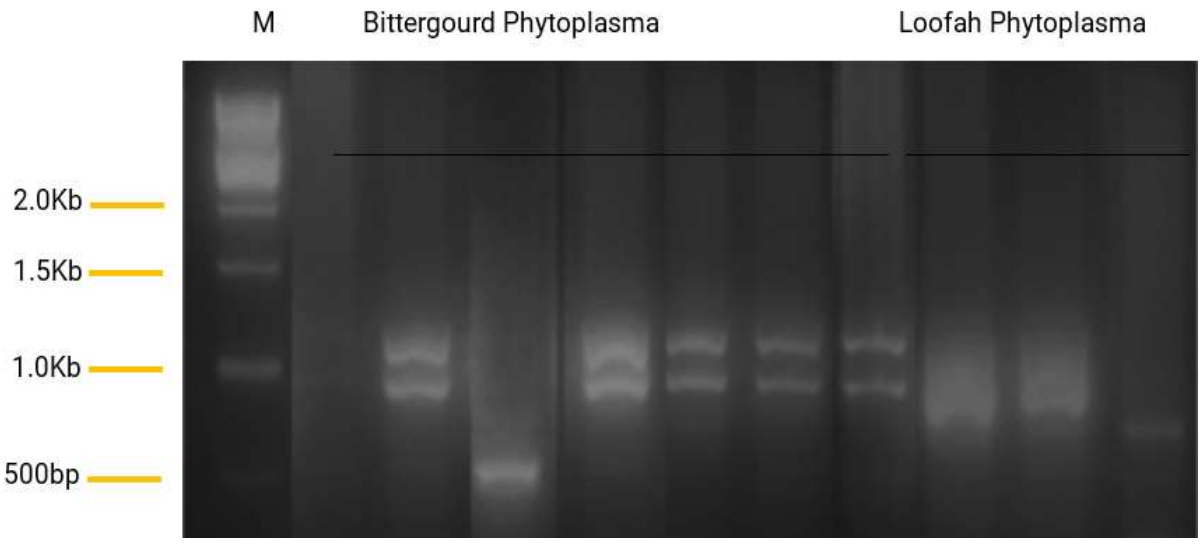

Figure 7. Restriction digests of R16F2N/R2 amplicons using Rsa1 enzyme showing two different band patterns for infected bitter gourd DNAs and three-band patterns for infected Loofah DNAs. M (1Kb DNA ladder Vivantis)

\section{rDNA Sequence Analysis}

Results of rDNA sequence analysis of the isolates is shown in (Tables 2, 3, 4 \& $5)$. Only three bitter gourds with $\sim 1.239 \mathrm{bp}$ amplicons had sequence results, ie, $A G$, $A L$ and $A V 2$. All three isolates were confirmed to be phytoplasma DNAs. Isolate AG 
showed $98-99 \%$ homology to Loofah witches' broom phytoplasma rRNA and Trnaile (AF353090.1, AF086621.2, AF248956.1, AB667970.1 \& Y17055.1) and 97\% similar to Stylosanthes little leaf phytoplasma (AJ289192.2), Malaysian periwinkle virescence and yellow dwarf phytoplasma (EU371934.2 \& EU498727.1), oil palm phytoplasma (EU498728.1), and Candidatus Phytoplasma trifolii Tomato-Zac (KX092011.1) (Table 2).

Bitter gourd isolate AL is $98 \%$ homologous to most Loofah phytoplasma rRNA and tRNA-ile gene accessions (AF353090.1, AF248956.1, AB667970.1 \& AF086621.2) and $96 \%$ homologous to stylosanthes little leaf phytoplasma (AJ289192.2), oil palm phytoplasma (EU498728.1), Malaysian yellow dwarf coconut and periwinkle virescence phytoplasma (EU498727.1 \& EU371934.2), and Candidatus Phytoplasma trifolii of tomato (KY321932.1).

Bitter gourd isolate AV2, on the other hand, is only $94-96 \%$ similar to Loofah witches' broom phytoplasma rRNA and tRNA-ile genes (AF353090.1, AF086621.2, AF248956.1 \& AB667970.1) and 94\% similar to stylosanthes little leaf phytoplasma (AJ289192.2), oil palm phytoplasma (EU498728.1), Malaysian yellow dwarf, and periwinkle virescence phytoplasma (EU371934.2) and 93\% similar to Cucumis sativus phyllody phytoplasma (KR633068.1).

The phytoplasma from baguio bean (Phaseolus vulgaris) showed $94-95 \%$ similarity to Loofah phytoplasma genes, stylosanthes little leaf phytoplasma, Malaysian periwinkle virescence, and yellow dwarf coconut phytoplasma, oil palm phytoplasma, and Candidatus phytoplasma ulmi (GU125723.1). Although no sequence result was produced from the string bean phytoplasma, it could be similar to the Baguio bean phytoplasma.

Three Loofah phytoplasma isolates were sequenced, namely PHg, PI, and PV. All three were $99 \%$ similar to Loofah witches' broom phytoplasma genes, $97 \%$ similar to stylosanthes little leaf phytoplasma, oil palm phytoplasma, Malaysian yellow dwarf coconut and periwinkle virescence phytoplasmas, and Candidatus Phytoplasma trifolii (Table 3). The tomato phytoplasma, on the other hand, (TG) is $96 \%$ similar to the same set of reference genes of phytoplasmas (Table 4 ).

The cucumber phytoplasma (CV) is $98 \%$ similar to most Loofah phytoplasma gene accessions and $96 \%$ similar to Stylosanthes little leaf phytoplasma, oil palm phytoplasma, Malaysian yellow dwarf coconut and Malaysian periwinkle virescence phytoplasmas, and Candidatus Phytoplasma trifolii (Table 3).

Multiple Sequence Alignment of 16srDNA sequences of eight phytoplasma samples (TG, BB, AL, AV2, PI, PV, AG, \& PHg) together with five phytoplasma taxa controls (AF353090.1, AF248956.1, L33764.1, AF086621.2, AB667970.1) and outgroup (rice rbcl) is shown in Figure 8. Alignment annotation from 180 to 270 nucleotide bases showed strong evidence of common haplotype pattern among the phytoplasma isolates, which is signified by high consensus value $(90 \%)$ indicated by the red-colored nucleotides. The blue-colored nucleotides indicate a low consensus value of $50 \%$, while the black-colored nucleotides have neutral consensus. The figure showed that the tomato phytoplasma (TG) is the most homologous to the consensus sequence, while the sample AV2 is most divergent.

The phylogenetic dendrogram of fourteen nucleotide sequences, including eight phytoplasma isolates and 6 reference genes from the Genbank, was analyzed (Figure 9). The evolutionary relationship of taxa was inferred using the UPGMA method (Sneath \& Sokal 1973). The optimal tree with the sum of branch length $=2.70641489$ is shown. 
Detection and molecular characterization of phytoplasma

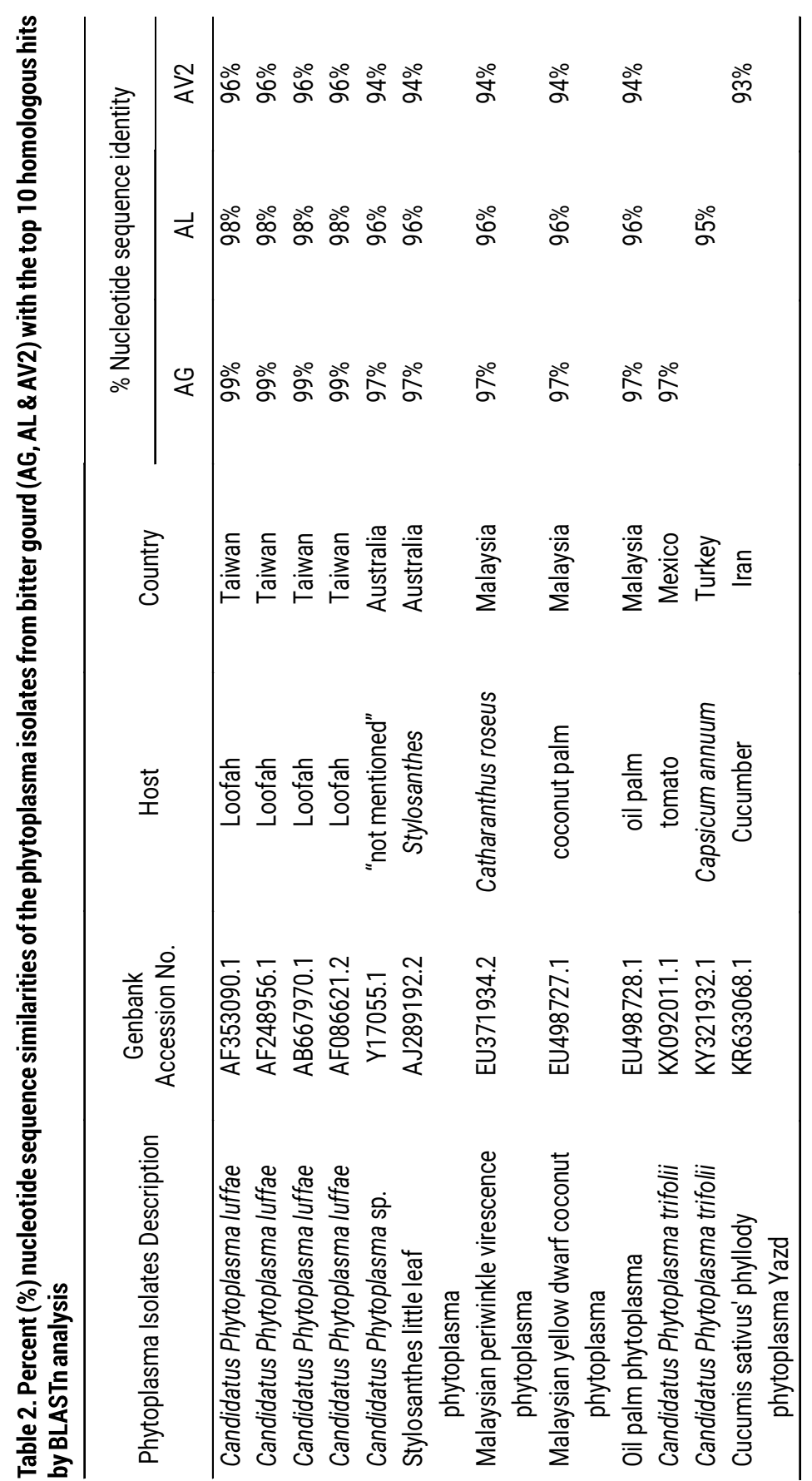




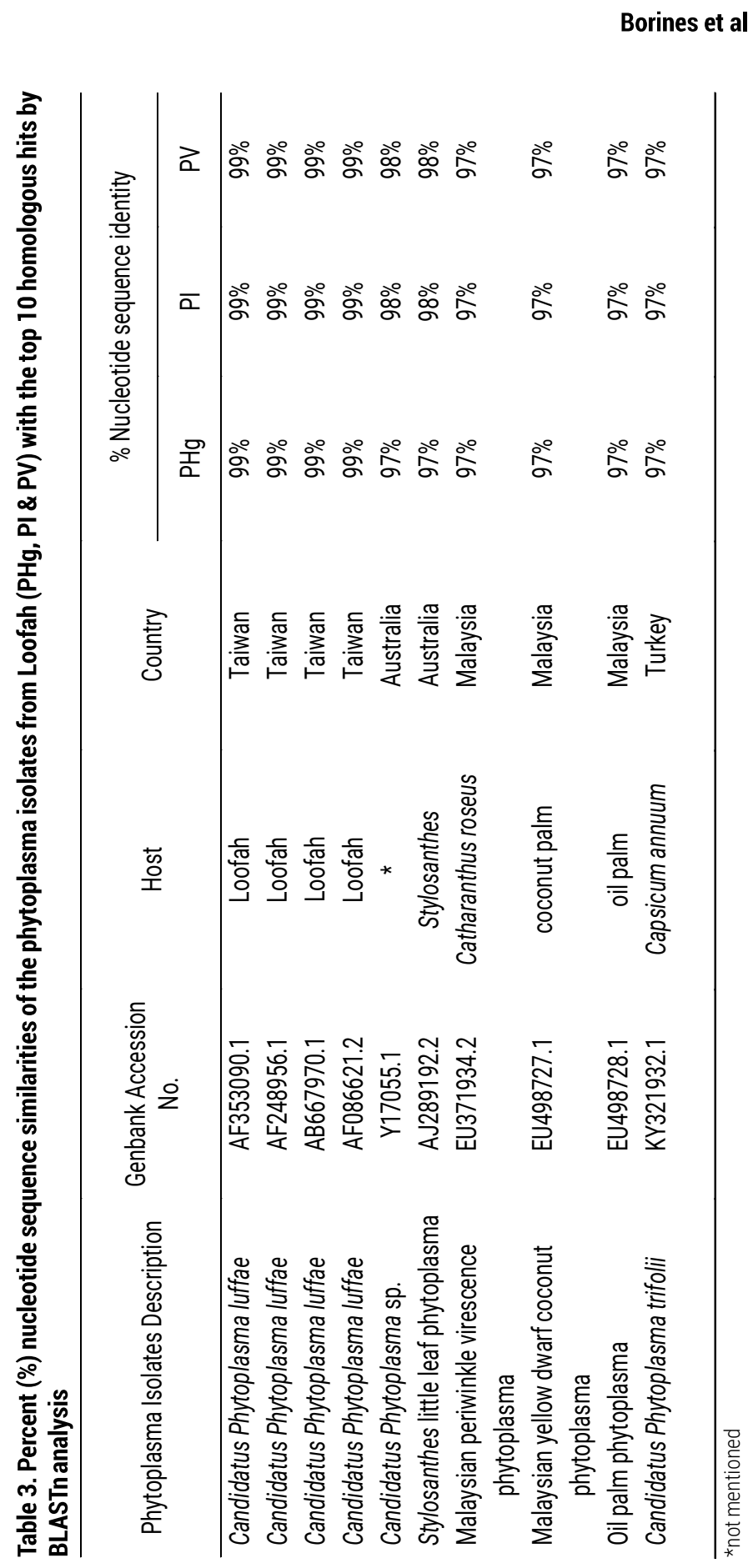


Detection and molecular characterization of phytoplasma

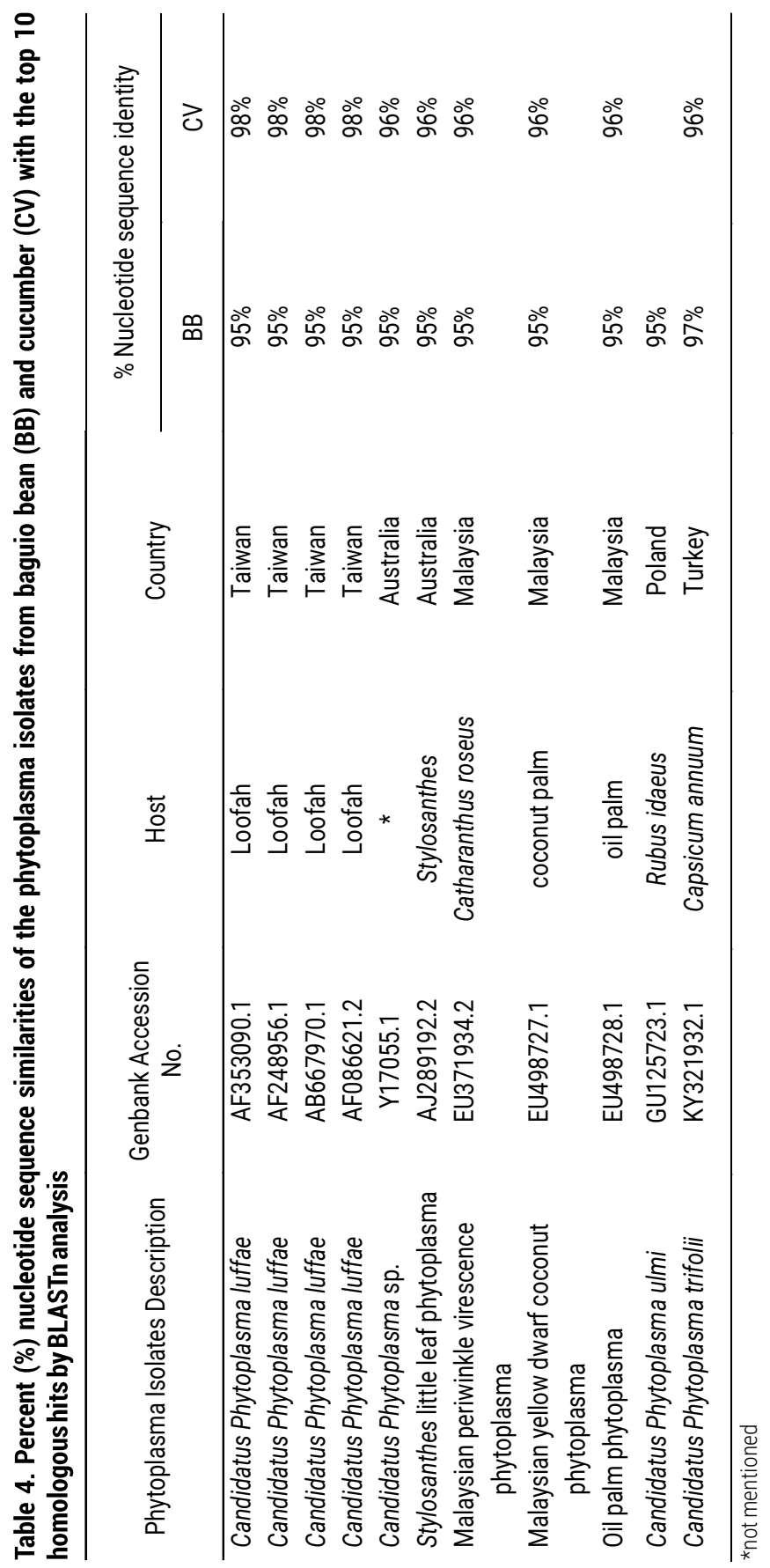


Borines et al

Table 5. Percent (\%) nucleotide sequence similarities of the phytoplasma isolate from tomato (TG) with the top 10 homologous hits by BLASTn analysis

\begin{tabular}{|c|c|c|c|c|}
\hline $\begin{array}{c}\text { Phytoplasma Isolates } \\
\text { Description }\end{array}$ & $\begin{array}{c}\text { Genbank } \\
\text { Accession No. }\end{array}$ & Host & Country & $\begin{array}{c}\% \text { Nucleotide } \\
\text { sequence identity }\end{array}$ \\
\hline $\begin{array}{l}\text { Candidatus Phytoplasma } \\
\text { luffae }\end{array}$ & AF353090.1 & Loofah & Taiwan & $96 \%$ \\
\hline $\begin{array}{l}\text { Candidatus Phytoplasma } \\
\quad \text { luffae }\end{array}$ & AF248956.1 & Loofah & Taiwan & $96 \%$ \\
\hline $\begin{array}{l}\text { Candidatus Phytoplasma } \\
\text { luffae }\end{array}$ & AB667970.1 & Loofah & Taiwan & $96 \%$ \\
\hline $\begin{array}{l}\text { Candidatus Phytoplasma } \\
\text { luffae }\end{array}$ & AF086621.2 & Loofah & Taiwan & $96 \%$ \\
\hline $\begin{array}{l}\text { Candidatus Phytoplasma } \\
\quad \text { luffae }\end{array}$ & L33764.1 & $\begin{array}{l}\text { Catharanthus } \\
\text { roseus }\end{array}$ & * & $96 \%$ \\
\hline $\begin{array}{l}\text { Cape St. Paul wilt } \\
\text { phytoplasma }\end{array}$ & KF419286.1 & Coconut & $\begin{array}{c}\text { Cote } \\
\text { d'Ivoire }\end{array}$ & $96 \%$ \\
\hline $\begin{array}{c}\text { Cape St. Paul wilt } \\
\text { phytoplasma }\end{array}$ & KF387570.1 & Coconut & $\begin{array}{l}\text { Cote } \\
\text { d'Ivoire }\end{array}$ & $96 \%$ \\
\hline $\begin{array}{l}\text { Cape St. Paul wilt } \\
\text { phytoplasma }\end{array}$ & KF364359.1 & Coconut & $\begin{array}{l}\text { Cote } \\
\text { d'Ivoire }\end{array}$ & $96 \%$ \\
\hline $\begin{array}{c}\text { Cape St. Paul wilt } \\
\text { phytoplasma }\end{array}$ & JQ868442.1 & Coconut & Ghana & $96 \%$ \\
\hline $\begin{array}{c}\text { Cape St. Paul wilt } \\
\text { phytoplasma }\end{array}$ & Y13912.1 & Coconut & * & $96 \%$ \\
\hline
\end{tabular}

*not mentioned

The percentage of replicate trees in which the associated taxa clustered together in the bootstrap test (1000 replicates) is shown next to the branches (Felsenstein 1985). The tree is drawn to scale, with branch lengths in the same units as those of the evolutionary distances used to infer the phylogenetic tree. The evolutionary distances were computed using the Kimura 2-parameter method (Kimura 1980) and are in the units of the number of base substitutions per site. The analysis involved 14 nucleotide sequences. Codon positions included were $1 s t+2 n d+3 r d+N o n c o d i n g$. All positions containing gaps and missing data were eliminated. There were a total of 187 positions in the final dataset. Evolutionary analyses were conducted in MEGA6 (Tamura et al 2013).

The phylogenetic tree showed that bitter gourd phytoplasma samples AL, AV2, $\mathrm{AG}$, and sponge gourd samples $\mathrm{PI}, \mathrm{PV}$, and $\mathrm{PHG}$ clustered together and were found to be very related (divergence value $=0$ ) and are quite distant from "Baguio" bean $(\mathrm{BB})$ and Tomato phytoplasmas. Tomato stunt phytoplasma (TG) clustered together with Baguio bean phytoplasma and most of the reference phytoplasmas. Results of the partial sequence analysis of 16SrDNA confirmed that phytoplasma caused the little leaf/witches' broom symptoms in bitter gourd, Loofah, Baguio bean, and tomato. Sequence analysis also revealed slight differences in their rRNA sequence confirming the existence of different phytoplasma strains infecting these vegetables in Eastern Visayas. 
Detection and molecular characterization of phytoplasma
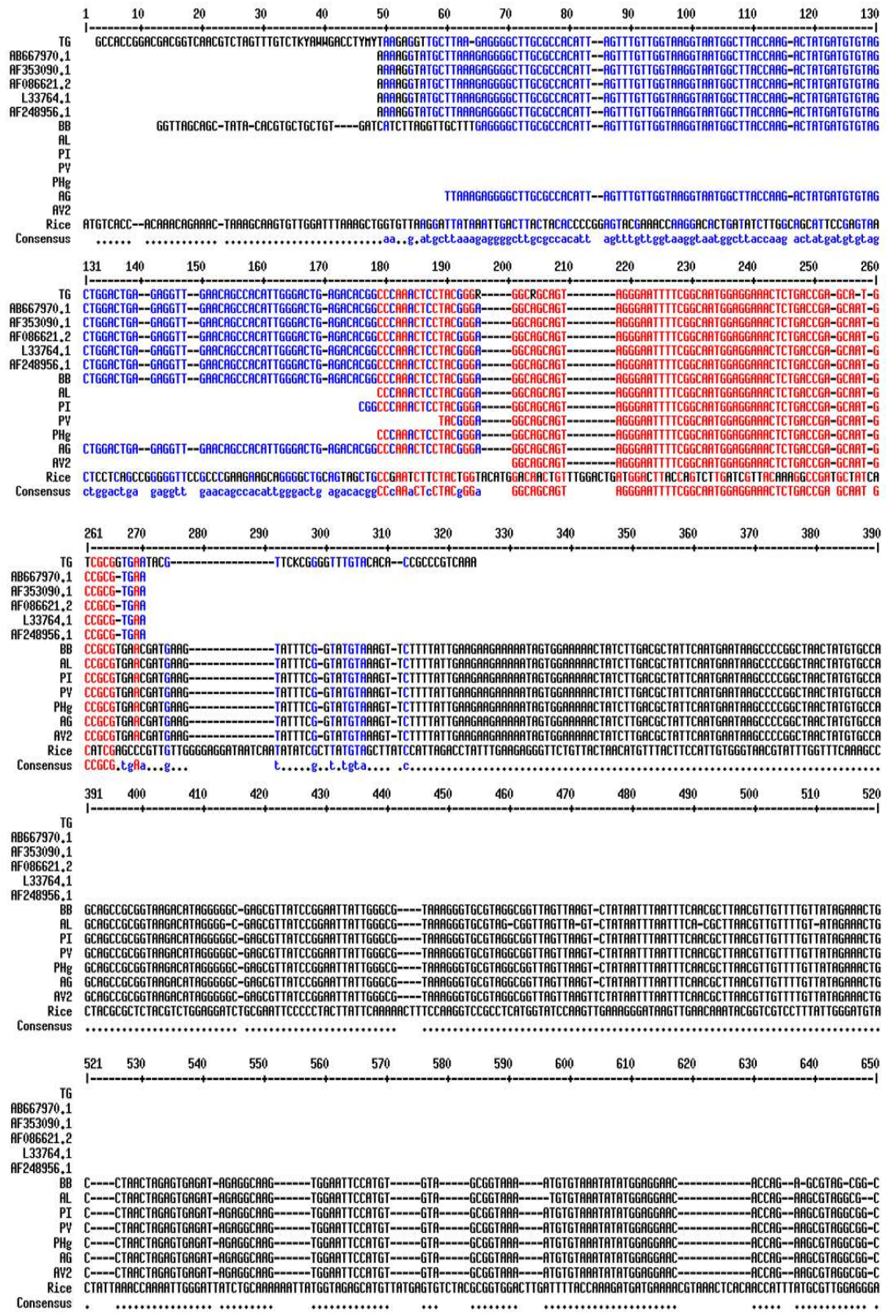

Figure 8. Multiple Sequence Alignment of eight 16srDNA sequences of eight phytoplasma samples (TG, BB, AL, AV2, PI, PV, AG, PHg) together with five phytoplasma taxa controls (AF353090.1, AF248956.1, L33764.1, AF086621.2, AB667970.1) and outgroup (rice rbcl) 
Borines et al

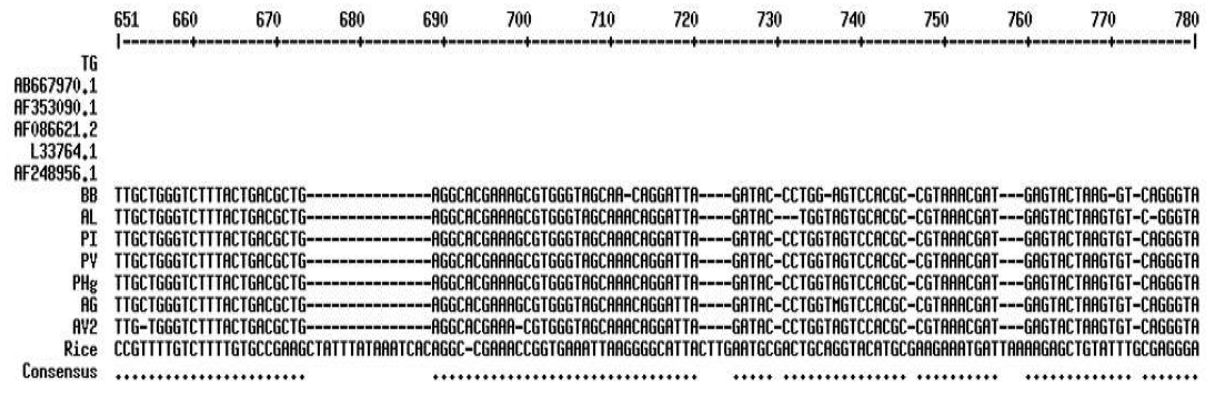

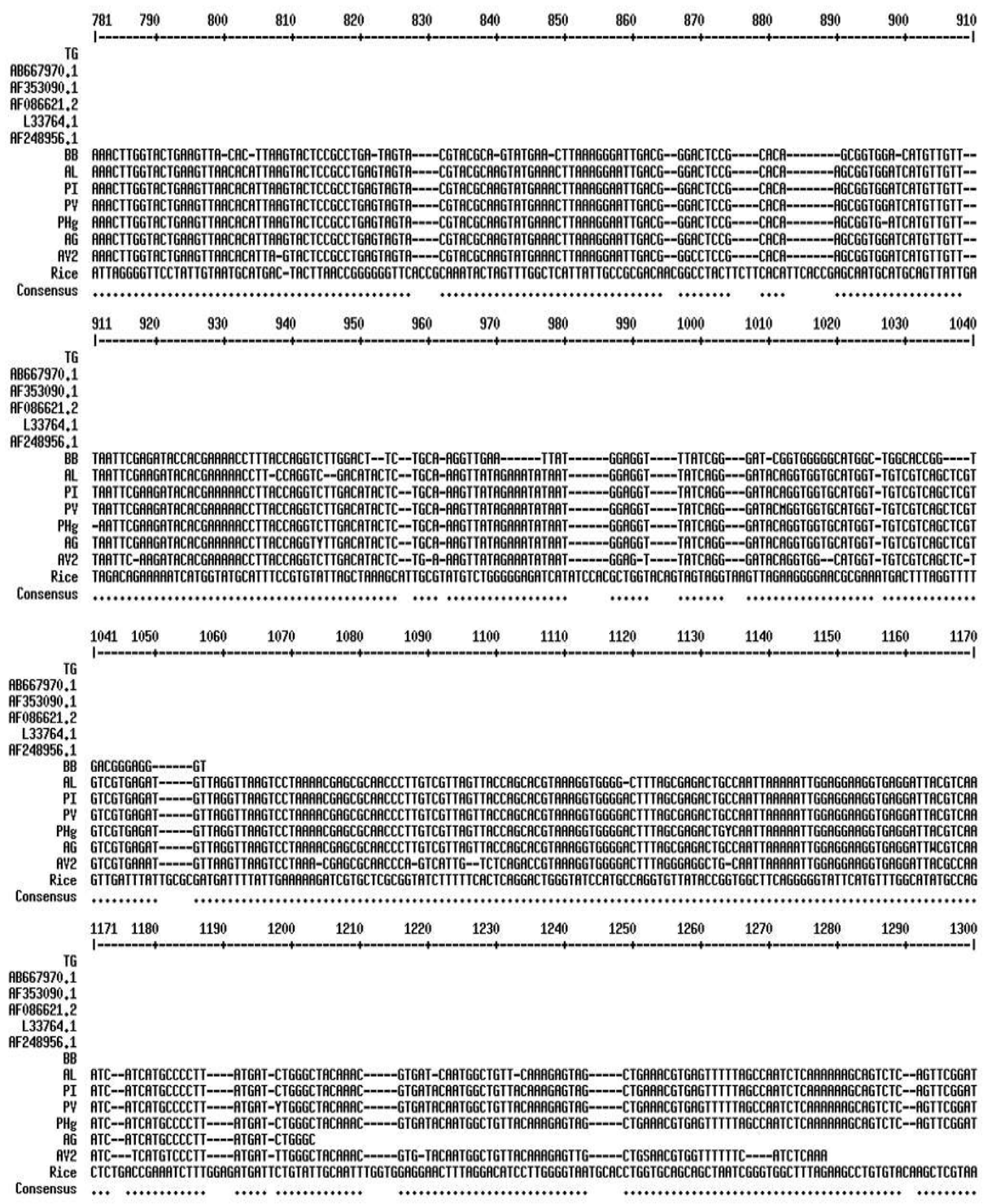

Figure 8 continued 
Detection and molecular characterization of phytoplasma

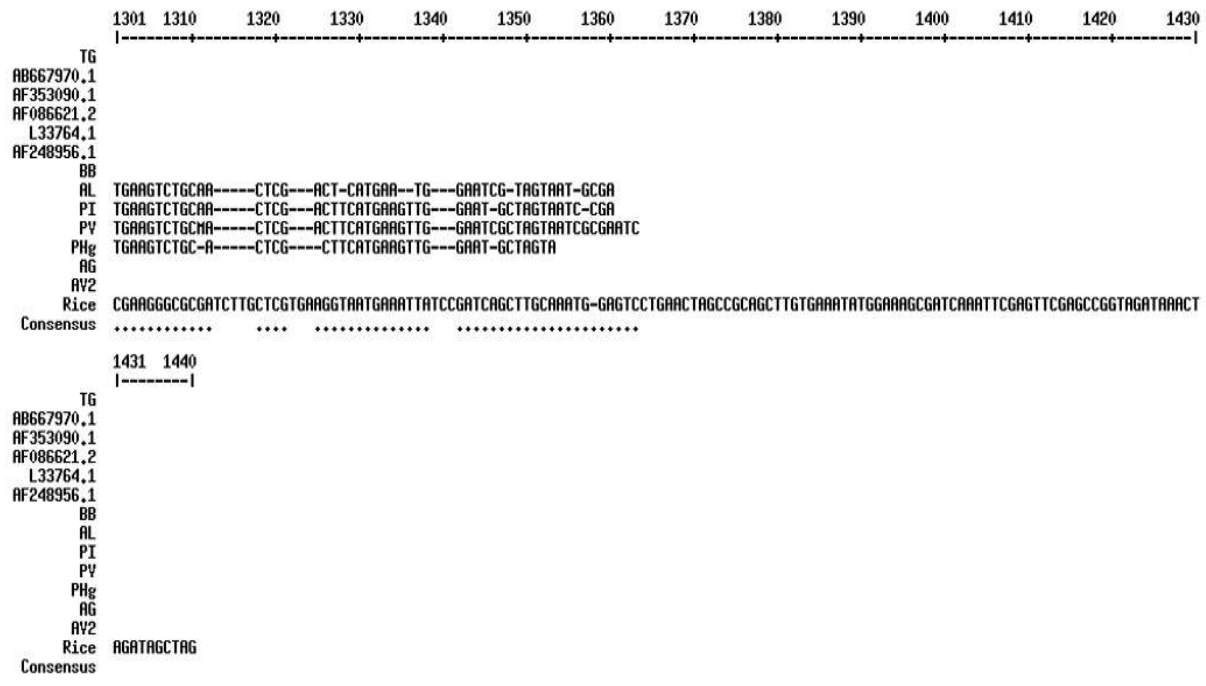

Figure 8 continued

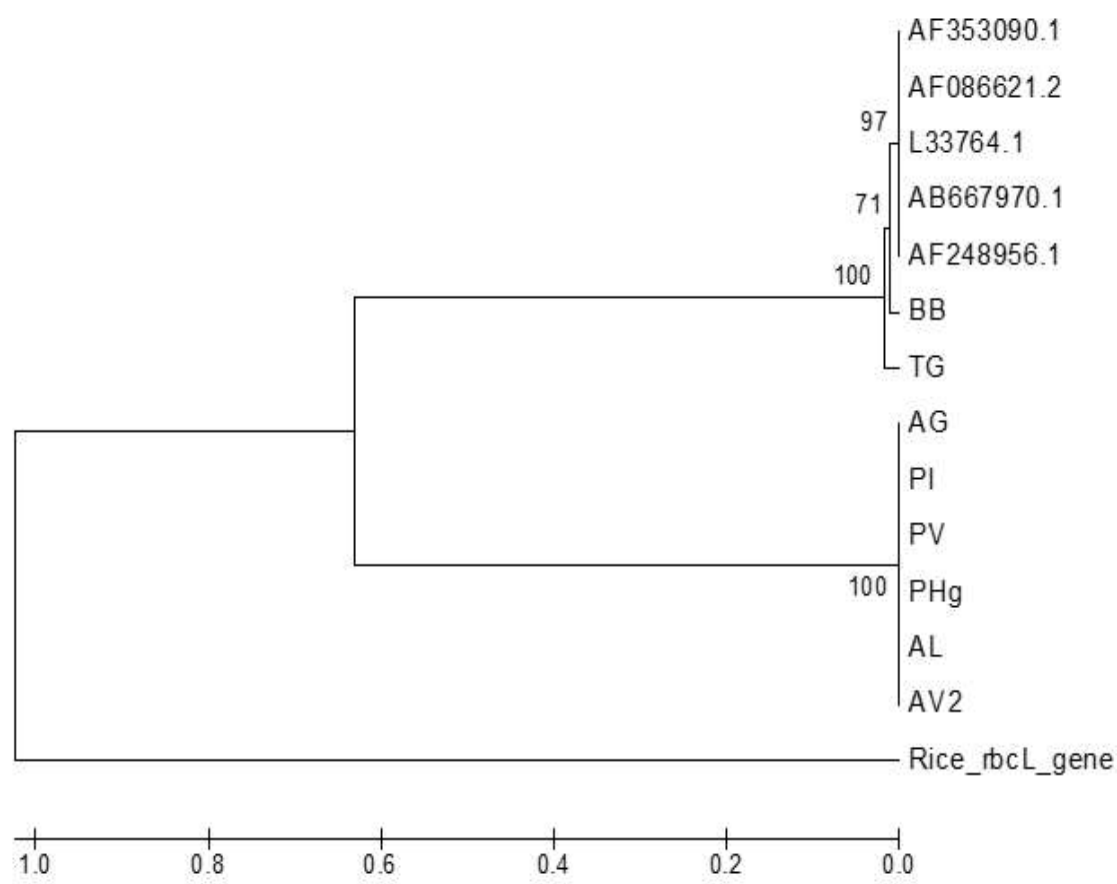

Figure 9. Phylogenetic dendrogram of fourteen phytoplasma nucleotide sequences, (three from bitter gourd (AG, Al, \& AV2), three from Loofah, one "Baguio" bean, and one tomato, with 6 reference genes (Genebank accessions: AF353090.1, AF086621.2, L33764.1, AB667970.1, and AF248956.1) analyzed using UPGMA method 


\section{CONCLUSION, IMPLICATION, AND RECOMMENDATION}

The study confirms that bitter gourd, Loofah, string bean, "Baguio" bean, cucumber, and tomato showing little leaf, witches' broom, and phyllody symptoms in Eastern Visayas Philippines are caused by phytoplasma. More than one strain of phytoplasma is infecting these vegetables based on nest PCR assay, rsa1 enzyme digestion, and rDNA sequence analysis. The specific phytoplasma strains affecting these vegetables need to be confirmed in future studies. Further studies on their control are also deemed necessary. The disease is getting more common, thereby implying the need for immediate mitigation of the problem. Vegetable growers must be educated on the disease's occurrence and must be familiarized with the symptoms and dissemination methods.

\section{ACKNOWLEDGMENT}

The authors wish to acknowledge the Philippine Council for Agriculture Aquatic and Natural Resources Research and Development (PCAARRD) through the former and current executive directors Dr. Patricio S. Faylon and Dr. Reynaldo V. Ebora respectively, and the Australian Centre for International Agricultural Research (ACIAR) for the research funds through Dr. Sandra McDougall and Dr. Gordon Rogers. Special thanks are also given to the late Dr. Jocelyn E. Eusebio, Ms. Leilani D. Pelegrina, and other staff of the PCAARRD's Crop Research Division for all the support given to the project. Special thanks are also given to Dr. Len Tesoriero of New South Wales Department of Trade and Industries, Sydney, Australia, for his contribution to this work.

\section{REFERENCES}

Ahrens U and Seemuller E. 1992. Detection of DNA of plant pathogenic mycoplasma like organisms by a polymerase chain reaction amplifies a sequence of the 16S rRNA gene. Phytopathology 82(8):828-832

Almomani $\mathrm{F}$ and Almuaikel N. 2014. Molecular detection of phytoplasma from different infected hosts in Jordan based on the PCR amplification of 16srDNA sequences. Proceedings of the 3rd International Conference on Medical, Biological, and Pharmaceutical Sciences (ICMBPS'2014) (pp115-117), March 19-20, 2014 Abu Dhabi, UAE

Al-Saleh MA and Amer MA. 2014. Molecular characterization of the 16sRII group of a phytoplasma associated with faba bean (Vicia faba) in Saudi Arabia. The Journal of Animal \& Plant Sciences 24(1):221-228

Bertaccini A. 2007. Phytoplasmas: diversity, taxonomy, and epidemiology. Frontieres in Bioscience: a journal and virtual library 12:673-689

Bertaccini A, Duduk B, Paltrinieri S \& Contaldo N. 2014. Phytoplasmas and Phytoplasma diseases: a severe threat to agriculture. American Journal of Plant Sciences 5(12):1763-1788

Bertaccini A and Duduk B. 2009. Phytoplasma and phytoplasma diseases: A review of recent research. Phytopathologia Mediterranea 48:355-378

Deng S and Hiruki C. 1991. Genetic relatedness between two noncultureable mycoplasma-like organisms reaveled by nucliec acid hybridization and polymerase chain reaction. Phytopathology 81(12):1475-1479 


\section{Detection and molecular characterization of phytoplasma}

Duleep KS, Reddy MK, Jalali S \& Reddy HC. 2014. Sensitive detection of phytoplasmal infection in vegetable cby secA gene. Current Biotica 8(2):165173

Felsenstein J. 1985. Confidence limits on phylogenies: An approach using the bootstrap. Evolution 39(4):783-791

Gundersen DE and Lee IM. 1996. Ultrasensitive detection of phytoplasmas by nested-PCR assays using two universal primer pairs. Phytopathologia Mediterranea 35(3):144-151

Habili N, Wu Q, Sta. Cruz FC, Huan KH, Jormasiea J, Lanisat NB \& Randles JW. 2014. ASEAN Regional Diagnostic Network: Results of a survey on the detection of viruses and virus-like pathogens in selected ASEAN countries. 11th Australasian Plant Virology Workshop. Plant virology in the 'omics' era Handbook

Khan AJ, Botti S, Al-subhi AM, Zaidi MA, Altosaar I, Alma A \& Bertaccini A. 2003. Molecular characterization of the 16S rRNA gene of phytoplasmas detected in two leafhopper species associated with alfalfa plants infected with witches' broom in Oman. Phytopathologia Mediterranea 42(3):257-267

Kimura M. 1980. A simple method for estimating evolutionary rate of base substitutions through comparative studies of nucleotide sequences. Journal of Molecular Evolution 16(2):111-120

Kummert J and Rufflard G. 1997. A Preliminary Report on the Detection of Phytoplasmas by PCR. Biochemica 1:19-22

Lebsky V, Gonzalez J, Astorga G, Conejo Y \& Poghosyan A. 2007. Detection of phytoplasmas in mixed Infection with Begomoviruses: A case study of tomato and pepper in mexico. Bulletin of Insectology 64 (Supplement): S55-S56

Lee IM, Bertaccini A, Vibio M \& Gundersen DE. 1995. Detection of multiple phytoplasmas in perennial fruit trees with decline symptoms in Italy. Phytopathology 85(6):728-735

Lee IM, Gundersen RD, Davis RE \& Bartoszyk IM. 1998. Revised classification scheme of phytoplasmas based on RFLP analysis of 16S rRNA and ribosomal protein gene sequences. International Journal of Systematic Bacteriology 48(4):1153-1169

Montano HG, Davis RE, Dally EL, Pimentel JP \& Brioso PST. 2000. Identification and phylogenetic analysis of a new phytoplasma from diseased chayote in Brazil. Plant Disease 84(4):429-436

Montano HG, Davis RE, Dally EL, Hogenhouts S, Pimentel JP \& Brioso PST. 2001. 'Candidatus Phytoplasma brasiliense', a new phytoplasma taxon associated with hibiscus witches' broom disease. International Journal of Systematic and Evolutionary Microbiology 51:1109-1118

Montano HG, Brioso PST, Pimentel JP, Figuerido DV \& Cunha JO Jr. 2006. Cucurbita moschata, new phytoplasma host in Brazil. Journal of Plant Pathology 88:226226

Montano HG, Brioso PST, Cunha JO Jr, Figuerido DV \& Pimentel JP. 2007. First report of group $16 \mathrm{Srlll}$ phytoplasma in loofah (Luffa cylindrica). Bulletin of Insectology 60(2):277-278

Nang KKW, Young HK \& Hee YJ. 2014. Bitter Gourd Little Leaf Disease-Associated to 'Candidatus Phytoplasma asteris'. Tropical Plant Pathology 39(1):082-088 
Saitou $N$ and Nei M. 1987. The neighbor-joining method: A new method for reconstructing phylogenetic trees. Molecular Biology and Evolution 4(4):406425

Samuel DK, Reddy MK, Jalali S \& Reddy HC. 2014. Sensitive detection of phytoplasmal infection in vegetable crops by secA gene. Current Biotica 8(2):165-173

Schneider B, Gibb KS \& Seemuller E. 1997. Sequence and RFLP analysis of the elongation factor Tu gene used in differentiation and classification of phytoplasmas. Microbiology 143(10):3381-3389

Singh D and Singh SJ. 2000. Chilli little leaf - a new phytoplasma disease in India. Indian Phytopathological Society 53(3):309-310

Sneath PHA and Sokal RR. 1973. The estimation of taxonomic resemblance. In Kennedy D, Park RB (eds) Numerical Taxonomy (pp129-132). The principles and Practice of Numerical Classification. Freeman, San Francisco

Tamura K, Stecher G, Peterson D, Filipski A \& Kumar S. 2013. MEGA6: Molecular Evolutionary Genetics Analysis version 6.0. Molecular Biology and Evolution 30(12):2725-2729 